\title{
Abbreviations for Standard Editions
}

Roman and Arabic numerals refer to volume and page numbers of Maksym Komyshanchenko's historical-critical edition Ol'ha Kobylians'ka: Tvory $v$ piaty tomakh. Kyiv: Derzhavne vydavnytstvo khudozhn'oi literatury, 1962-3.

I = Ol'ha Kobylians'ka: Tvory v piaty tomakh. Vol. 1. 1962. Edited by Maksym Komyshanchenko. Kyiv: Derzhavne vydavnytstvo khudozhn'oi literatury.

II $=$ Ol'ha Kobylians'ka: Tvory v piaty tomakh . Vol. 2. 1962. Edited by Maksym Komyshanchenko. Kyiv: Derzhavne vydavnytstvo khudozhn'oi literature.

III = Ol'ha Kobylians'ka: Tvory v piaty tomakh. Vol. 3. 1963. Edited by Maksym Komyshanchenko. Kyiv: Derzhavne vydavnytstvo khudozhn'oi literatury.

IV = Ol'ha Kobylians'ka: Tvory v piaty tomakh. Vol. 4. 1963. Edited by Maksym Komyshanchenko. Kyiv: Derzhavne vydavnytstvo khudozhn'oi literatury.

$\mathrm{V}=$ Ol'ha Kobylians'ka: Tvory v piaty tomakh. Vol. 5. 1963. Edited by Maksym Komyshanchenko. Kyiv: Derzhavne vydavnytstvo khudozhn'oi literatury.

Arabic numerals refer to volume and page numbers of Oleh Babyshkin's edition Ol'ha Kobylians'ka: Tvory v tr'okh tomakh (Kyiv: Derzhavne vydavnytstvo khudozhn'oi literatury, 1956). 
$1=$ Ol'ha Kobylians'ka: Tvory v tr'okh tomakh . Vol. 1. 1956. Edited by Oleh Babyshkin. Kyiv: Derzhavne vydavnytstvo khudozhn'oi literatury. $2=$ Ol'ha Kobylians'ka: Tvory v tr'okh tomakh . Vol. 2. 1956. Edited by Oleh Babyshkin. Kyiv: Derzhavne vydavnytstvo khudozhn'oi literatury. $3=$ Ol'ha Kobylians'ka: Tvory v tr'okh tomakh. Vol. 3. 1956. Edited by Oleh Babyshkin. Kyiv: Derzhavne vydavnytstvo khudozhn'oi literatury. 